\title{
FAKTOR KEUANGAN DAN KUALITAS LABA
}

\author{
Siti Hanifah ${ }^{1}$, Dirvi Surya Abbas ${ }^{2}$, Mohamad Zulman Hakim ${ }^{3}$ \\ Universitas Muhammadiyah Tangerang ${ }^{1,2,3}$ \\ Email korespondensi: hanifahnifah02@gmail.com
}

\begin{abstract}
Abstrak: Penelitian ini bertujuan untuk membuktikan pengaruh investment opportunity set (ios), leverage, profitabilitas, likuiditas, ukuran perusahaan, pertumbuhan laba terhadap kualitas laba yang terdapat pada perusahaan sektor Consumer Goods Industry yang terdaftar di Bursa Efek Indonesia (BEI). Periode waktu penelitian yang digunakan adalah empat tahun yaitu periode 2015-2018. Populasi dalam penelitian adalah seluruh perusahaan sektor Consumer Goods Industry yang terdaftar di Bursa Efek Indonesia (BEI) periode 2015-2018. Pengambilan sampel menggunakan teknik purposive sampling dengan jumlah sampel yaitu sebanyak 11 perusahaan sektor Consumer Goods Industry.Jenis data yang digunakan dalam penelitian ini adalah jenis data sekunder yang diperoleh dari Bursa Efek Indonesia (BEI). Metode analisis yang digunakan yaitu metode analisis regresi data panel dengan menggunakan program Eviews versi 10.0. Hasil penelitian ini membuktikan bahwa variabel profitabilitas yang diproksikan oleh return on asset (ROA), likuiditas yang diproksikan oleh current ratio (CR), dan pertumbuhan laba berpengaruh terhadap kualitas laba, sedangkan variabel investment opportunity set (ios), leverage yang diproksikan oleh debt to equity ratio (DER) dan ukuran perusahaan yang diproksikan dengan total aset tidak memiki pengaruh terhadap kualitas laba.

Kata Kunci: Kualitas Laba, Investment Opportunity Set (IOS), Leverage, Profitabilitas, Likuiditas, Ukuran Perusahaan, Pertumbuhan Laba.
\end{abstract}

Informasi keuangan menjadi kebutuhan utama yang diperlukan bagi para investor di pasar modal dalam menentukan keputusan ekonomi. Informasi keuangan dapat digunakan oleh investor sebagai bahan pertimbangan dalam pengambilan keputusan penanaman modal ke suatu perusahaan. Salah satu sarana yang digunakan oleh pihak manajemen untuk menunjukkan kinerja perusahaan dapat berupa laporan keuangan, dimana melalui laporan keuangan, calon investor dan stakeholder melihat kondisi perusahaan. Salah satu item yang sangat diperhatikan adalah laba perusahaan. Laba perusahaan yang berkualitas tentu dapat dijadikan sebagai informasi penting bagi calon investor dan stakeholder dalam menentukan suatu keputusan yang tepat (Murniati et al., 2018). Kualitas laba yang rendah tentunya akan membuat kesalahan pengambilan keputusan bagi para pemakainya seperti investor dan kreditor. Tingginya kualitas laba dapat dilihat dari kualitas laba suatu perusahaan dimana laba yang dilaporkan tersebut dapat digunakan oleh pengguna laporan keuangan untuk membuat keputusan yang terbaik dan memenuhi karakteristik kualitatif laporan keuangan yaitu relevan dan reliabilitas. Perusahaan yang besar dianggap mampu untuk terus meningkatkan kinerja perusahaannya dengan berupaya meningkatkan kualitas labanya serta memiliki informasi yang lebih banyak dibandingkan perusahaan kecil sehingga investor lebih percaya untuk menanamkan investasi mereka pada perusahaan yang besar. Hal ini menunjukkan bahwa suatu ukuran perusahaan dapat menentukan baik atau tidaknya kinerja dari perusahaan (Warianto \& Rusiti, 2014). 
Kualitas laba yang kurang baik terjadi pada perusahaan yang bergerak dalam bidang usaha minuman dan produk kecantikan yaitu PT Akasha Wira International Tbk (ADES) dimana perusahaan ini mencatatkan penurunan laba bersih yang cukup signifikan. Dapat dilihat pada diagram berikut:

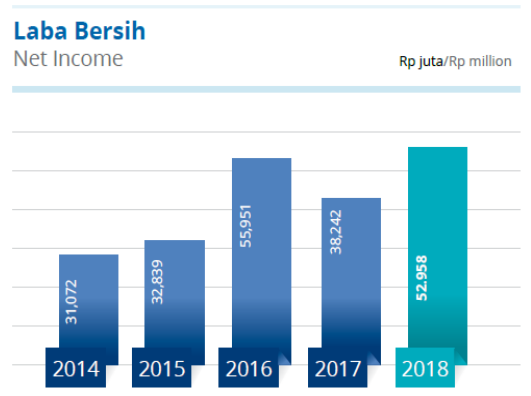

Gambar 1. Grafik Penurunan Kualitas Laba PT ADES

Sumber: www.idx.co.id, diolah

Laba bersih PT ADES pada tahun 2017 mengalami penurunan 31,6\% atau sebesar $\mathrm{Rp} 38,42$ miliar jika dibandingkan dengan tahun sebelumnya yaitu sebesar Rp 55,95 miliar. Laba kotor PT ADES di tahun 2017 juga menurun menjadi Rp 438,94 miliar, hal tersebut didorong dengan adanya penjualan yang juga menurun pada periode tersebut. Selain itu, beban keuangan dan beban pajak penghasilan meningkat, sehingga laba perseroan menurun. Oleh karena itu, laba bersih per saham juga terpangkas menjadi $\mathrm{Rp} 65$ per saham dari Rp 95 per saham di tahun sebelumnya (Sumber: https://www.idnfinancials.com). Fenomena yang terjadi pada PT Akasha Wira International Tbk (ADES) merupakan salah satu bukti bahwa laporan keuangan suatu perusahaan sangatlah penting untuk menunjukkan informasi yang sebenarnya tentang kinerja manajemen yang berdampak pada seluruh pihak pengguna laporan keuangan. Beberapa variabel yang mempengaruhi kualitas laba yang dipilih penulis dalam penelitian diantaranya yaitu: rasio investment opportunity set (IOS), leverage, profitabilitas, likuiditas, ukuran perusahaan, dan pertumbuhan laba.

Investment opportunity set dapat didefinisikan sebagai keputusan investasi dapat berupa kombinasi aktiva yang dimiliki oleh perusahaan dan pilihan investasi perusahaan dimasa yang akan datang (Wulansari, 2013). Tingkat investment opportunity set yang tinggi dapat menggambarkan tinggi rendahnya kemampuan perusahaan untuk memperoleh labanya. Oleh karena itu reaksi pasar akan memberikan reaksi lebih tinggi terhadap perusahaan yang memiliki kesempatan bertumbuh. Tingginya respon pasar terhadap laba mengindikasikan bahwa perusahaan memiliki kualitas laba yang baik (Mulyani et al, 2007) dalam (Wulansari, 2013).

Variabel leverage didapat diukur dengan menggunakan Debt to Equity Ratio (DER) yaitu membandingkan antara total kewajiban dengan 
total ekuitas dari suatu perusahaan periode tertentu (Murniati et al., 2018). Tingkat leverage yang tinggi dapat mengakibatkan investor berfikir ulang untuk berinvestasi pada perusahaan sehingga mengakibatkan respon pasar menjadi relatif rendah. Kualitas laba yang rendah dapat dilihat dari semakin besarnya tingkat leverage suatu perusahaan (Wulansari, 2013).

Profitabilitas dapat mempengaruhi kualitas laba perusahaan, variabel ini menjelaskan bagaimana perusahaan mampu menghasilkan laba melalui sumber daya. Profitabilitas dapat diukur dengan Return on Asset (ROA). ROA didefinisikan sebagai kemampuan perusahaan dalam menghasilkan laba yang berasal dari total aset yang dimiliki perusahaan (Ginting, 2017).

Likuiditas perusahaan dapat diartikan sebagai kemampuan perusahaan dalam membayar utang jangka pendeknya yang telah jatuh tempo. Risiko yang dihadapi oleh perusahaan akan relatif kecil jika perusahaan tersebut memiliki tingkat likuiditas yang tinggi pula, sehingga memberikan keyakinan kreditur dalam memberikan pinjaman kepada perusahaan dan investor juga akan terdorong untuk melakukan investasi dananya pada perusahaan tersebut, karena investor yakin bahwa perusahaan mampu bertahan. Tingginya earnings response coefficients (ERC) mengindikasikan bahwa laba suatu perusahaan berkualitas. Semakin tinggi current ratio suatu perusahaan maka semakin berkualitas (Wulansari, 2013).

Secara umum ukuran perusahaan diproksikan dengan total aset. Karena nilai total aset biasanya sangat besar dibandingkan variabel keuangan lainnya (Ginting, 2017). Ukuran perusahaan dapat berhubungan langsung dengan kualitas laba sebab semakin besar ukuran suatu perusahaan maka kelangsungan usaha perusahaan tersebut akan semakin tinggi dalam meningkatkan keuangan sehingga perusahaan tidak perlu melakukan praktek manipulasi laba (Setiawan, 2017).

Pertumbuhan laba dapat dilihat dari naik turunnya laba bersih perusahaan yang diperoleh pada periode sekarang dibandingkan dengan laba tahun sebelumnya (Dewi, 2018). Menurut Hamid (2001) dalam (Dewi, 2018) merumuskan bahwa perusahaan yang bertumbuh adalah perusahaan yang memiliki pertumbuhan margin, laba dan penjualan yang tinggi. Jika pertumbuhan laba perusahaan tinggi maka para investor akan memberikan respon besar pada perusahaan tersebut karena perusahaan dapat memberikan manfaat di masa depan.

Data dalam penelitian ini diambil dari Bursa Efek Indonesia (BEl) khususnya pada perusahaan Manufaktur dalam sektor Consumer Goods Industry. Penelitian ini dilakukan untuk mengkaji ulang penelitianpenelitian sebelumnya yang masih memiliki hasil penelitian yang bervariasi mengenai pengaruh variabel tersebut terhadap kualitas laba serta untuk mengetahui faktor-faktor yang mempengaruhi kualitas laba, diantaranya: Investment Opportunity Set (IOS), Leverage, Profitabilitas, Likuiditas, Ukuran Perusahaan, dan Pertumbuhan Laba Terhadap Kualitas 
Laba pada Perusahaan Sektor Consumer Goods Industry yang Terdaftar di Bursa Efek Indonesia.

\section{METODE}

Jenis data yang digunakan dalam penelitian ini menggunakan data sekunder (secondary data), yakni data kuantitatif yang diambil dari 53 perusahaan yang merupakan seluruh perusahaan sektor consumer goods industry telah terdaftar di Bursa Efek Indonesia (BEI) selama periode 2015-2018. Data yang digunakan yaitu data laporan keuangan tahunan dalam kurun waktu 2015-2018 yang diakses langsung dari situs Bursa Efek Indonesia (BEI) www.idx.co.id. Perusahaan Sektor Consumer Goods Industry dipilih karena terdapat perusahaan yang paling banyak mengalami laba operasi negatif selama tahun 2015 hingga 2018. Hal ini mengindikasikan suatu kinerja perusahaan yang kurang baik atau merupakan suatu tahap penurunan kondisi keuangan perusahaan sehingga dapat mempengaruhi kualitas laba perusahaan.

Teknik pengambilan sampel dalam penelitian ini dilakukan dengan menggunakan teknik Purpose Sampling, yang berarti pemilihan sampel berdasarkan kriteria tertentu. Jumlah perusahaan yang memenuhi kriteria adalah sebanyak 14 perusahaan selama periode 2015-2018, sehingga jumlah data adalah 56 data. Dari 56 data tersebut dilakukan outlier sebanyak 3 data perusahaan sehingga jumlah data yang digunakan dalam penelitian ini adalah 11 perusahaan atau sebanyak 44 data. Dibawah ini adalah kriteria sampel yang digunakan adalah sebagai berikut:

a) Perusahaan sektor consumer goods industry yang terdaftar di Bursa Efek Indonesia (BEI) selama periode 2015-2018.

b) Perusahaan sektor consumer goods industry yang melaporkan laporan keuangan tahunan secara berturut-turut selama periode 20152018.

c) Perusahaan sektor consumer goods industry yang mengalami keuntungan selama berturut-turut selama periode penelitian.

d) Perusahaan sektor consumer goods industry yang menyampaikan data laporan keuangan menggunakan mata uang rupiah secara berturut-turut selama periode penelitian.

e) Perusahaan yang menyampaikan data secara lengkap selama periode penelitian serta berkaitan dengan variabel Investment opportunity set (IOS), leverage, profitabilitas, likuiditas, ukuran perusahaan, dan pertumbuhan laba.

a. Kualitas Laba

Dalam penelitian ini Kualitas Laba menggunakan pengukuran Quality of Income Ratio dimana Arus Kas Operasi dibagi Earnings Before Interest and Tax. Adapun hasil perhitungannya adalah sebagai berikut:

(Sumber: Murniati et al., 2018)

$$
\boldsymbol{Q R}=\frac{\text { Arus Kas Operasi }}{\text { Laba Bersih Sebelum Pajak }}
$$


Investment Opportunity Set (IOS) (X1)

Rasio Investment opportunity set (IOS) menunjukkan kesempatan perusahaan untuk tumbuh dimasa depan. Dimana Investment Opportunity Set diukur menggunakan rumus sebagai berikut:

$M V A / B V A=\{$ total aset - total ekuitas $+($ lembar saham beredar $x$ harga penutupan saham $)\} \div$ total aset

(Sumber: Wulansari, 2013)

\section{Leverage (X2)}

Perusahaan yang menggunakan lebih banyak utang dalam struktur modalnya dapat mencerminkan tingkat leverage yang tinggi. Dalam penelitian ini Leverage menggunakan pengukuran Debt to Equity Ratio dimana total hutang dibagi total ekuitas (Murniati et al., 2018). Adapun hasil perhitungannya adalah sebagai berikut:

$$
\text { DER }=\frac{\text { Total Hutang }}{\text { Total Ekuitas }} \times 100 \%
$$

(Sumber: Murniati et al., 2018)

\section{Profitabilitas (X3)}

Dalam penelitian ini Profitabilitas menggunakan pengukuran Return on Assets Ratio dimana Laba Bersih dibagi Total Aktiva. Adapun hasil perhitungannya adalah sebagai berikut:

$$
D E R=\frac{\text { Total Hutang }}{\text { Total Ekuitas }} \times 100 \%
$$

(Sumber: Ginting, 2017)

\section{Likuiditas (X4)}

Likuiditas diartikan sebagai rasio keuangan yang mengukur kemampuan perusahaan dalam menyelesaikan kewajiban jangka pendeknya. Variabel ini diukur dengan Current Ratio. dimana aktiva lancar dibagi hutang lancar(Murniati et al., 2018). Adapun hasil perhitungannya adalah sebagai berikut:

$$
C R=\frac{\text { Aktiva Lancar }}{\text { Hutang Lancar }} \times 100 \%
$$

(Sumber: Wulansari, 2013) 


\section{Ukuran Perusahaan (X5)}

Ukuran perusahaan merupakan rata-rata yang dihasilkan dari total penjualan bersih untuk tahun tersebut hingga beberapa tahun kedepan (Ginting, 2017). Adapun hasil perhitungammya sebagai berikut:

$\mathrm{UP}=\mathrm{Ln}$ (Total Assets)

(Sumber: Ginting, 2017)

\section{Pertumbuhan Laba (X6)}

Laba suatu perusahaan menjelaskan perbedaan antara pendapatan dengan keseimbangan biaya-biaya dan pengeluaran untuk periode tertentu. Dengan memprediksi laba, dapat diketahui prospek perusahaan tersebut dan mampu untuk memprediksi deviden yang akan diterima di masa mendatang serta dapat menentukan kualitas laba pada laporan keuangan.

$$
\text { Pertumbuhan Laba }=\text { Laba bersih th sekarang - Laba bersih th sebelumnira }
$$

(Sumber: Dewi, 2018)

\section{HASIL}

\begin{tabular}{|c|c|c|c|c|c|c|c|}
\hline & $\mathrm{KL}$ & IOS & LEV & PROF & LIK & UP & PL \\
\hline Mean & 1.181352 & 1.952493 & 0.631445 & 0.098768 & 3.086693 & 29.39261 & 0.114207 \\
\hline Median & 0.923150 & 1.350950 & 0.522250 & 0.100800 & 2.545200 & 28.87390 & 0.101900 \\
\hline Maximum & 5.446400 & 4.931400 & 1.954900 & 0.221900 & 8.637800 & 32.20100 & 0.848000 \\
\hline Minimum & 0.097600 & 0.154600 & 0.163500 & 0.006500 & 0.834300 & 27.20520 & -0.618100 \\
\hline Std. Dev. & 0.889746 & 1.411257 & 0.451958 & 0.056051 & 1.918948 & 1.628985 & 0.302211 \\
\hline Skewness & 3.000334 & 0.654009 & 1.167666 & 0.259704 & 1.093605 & 0.468193 & 0.121771 \\
\hline Kurtosis & 14.01198 & 2.185448 & 3.762334 & 2.400967 & 3.627321 & 1.773920 & 3.705739 \\
\hline Jarque-Bera & 288.3315 & 4.353080 & 11.06404 & 1.152479 & 9.491944 & 4.363498 & 1.021864 \\
\hline Probability & 0.000000 & 0.113433 & 0.003958 & 0.562008 & 0.008687 & 0.112844 & 0.599936 \\
\hline Sum & 51.97950 & 85.90970 & 27.78360 & 4.345800 & 135.8145 & 1293.275 & 5.025100 \\
\hline Sum Sq. Dev. & 34.04089 & 85.64084 & 8.783423 & 0.135096 & 158.3415 & 114.1044 & 3.927246 \\
\hline Observations & 44 & 44 & 44 & 44 & 44 & 44 & 44 \\
\hline
\end{tabular}

Tabel 1. Analisis Statistik Deskriptif

Sumber: Hasil Olahan Eviews 10.0, 2020.

Pemilihan Model Regresi Data Panel

Tabel 2. Uji Chow

\begin{tabular}{|lcrr|}
\hline Redundant Fixed Effects Tests & & & \\
Equation: Untitled \\
Test cross-section fixed effects
\end{tabular}

Sumber: Hasil Olahan Eviews 10.0, 2020. 
Tabel 3. Uji Hausman

\begin{tabular}{|lrrr|}
\hline $\begin{array}{l}\text { Correlated Random Effects - Hausman Test } \\
\text { Equation: Untitled } \\
\text { Test cross-section random effects } \\
\end{array}$ & & & \\
\hline \hline Test Summary & Chi-Sq. Statistic & Chi-Sq. d.f. & Prob. \\
\hline \hline Cross-section random & 2.205412 & 6 & 0.8999 \\
\hline \hline
\end{tabular}

Sumber: Hasil Olahan Eviews 10.0, 2020.

Tabel 4. Uji Lagrange Multiplier

\begin{tabular}{|c|c|c|c|}
\hline \multicolumn{4}{|c|}{$\begin{array}{l}\text { Lagrange multiplier (LM) test for panel data } \\
\text { Date: } 04 / 29 / 20 \text { Time: } 11: 04 \\
\text { Sample: } 20152018 \\
\text { Total panel observations: } 44 \\
\text { Probability in } 0\end{array}$} \\
\hline $\begin{array}{l}\text { Null (no rand. effect) } \\
\text { Alternative }\end{array}$ & $\begin{array}{l}\text { Cross-section } \\
\text { One-sided }\end{array}$ & $\begin{array}{l}\text { Period } \\
\text { One-sided }\end{array}$ & Both \\
\hline Breusch-Pagan & $\begin{array}{l}3.185917 \\
(0.0743)\end{array}$ & $\begin{array}{l}1.33 \mathrm{E}-06 \\
(0.9991)\end{array}$ & $\begin{array}{l}3.185918 \\
(0.0743)\end{array}$ \\
\hline
\end{tabular}

Sumber: Hasil Olahan Eviews 10.0, 2020.

\section{Kesimpulan Model}

Hasil pengujian disajikan dalam tabel sebagai berikut :

Tabel 5. Kesimpulan Pemilihan Model Regresi

\begin{tabular}{|c|l|l|l|}
\hline No & \multicolumn{1}{|c|}{ Metode } & Pengujian & Hasil \\
\hline 1. & Uji Chow & CEM vs FEM & CEM \\
\hline 2. & $\begin{array}{l}\text { Uji } \\
\text { Hausman }\end{array}$ & REM vs FEM & REM \\
\hline 3. & $\begin{array}{l}\text { Uji } \\
\text { Lagrange } \\
\text { Multiplier }\end{array}$ & CEM vs REM & CEM \\
\hline
\end{tabular}

Jika dilihat dari ketiga pengujian yang sudah dilakukan maka dapat disimpulkan bahwa Model Regresi Data Panel yang akan digunakan dalam Uji Hipotesis dan Persamaan Regresi Data Panel adalah model Common Effect Model (CEM), maka diperlukan Uji Asumsi Klasik.

Uji Asumsi Klasik

Tabel 6. Uji Multikolinieritas

\begin{tabular}{|c|c|c|c|c|c|c|c|}
\hline & $\mathrm{KL}$ & $10 S$ & LEV & PROF & LIK & UP & $\mathrm{PL}$ \\
\hline $\mathrm{KL}$ & 1.000000 & -0.314053 & 0.284471 & -0.466387 & -0.104933 & -0.275804 & 0.083539 \\
\hline IOS & -0.314053 & 1.000000 & -0.340205 & 0.588671 & 0.278978 & 0.294491 & -0.024136 \\
\hline LEV & 0.284471 & -0.340205 & 1.000000 & -0.718078 & -0.730199 & 0.041861 & 0.057150 \\
\hline PROF & -0.466387 & 0.588671 & -0.718078 & 1.000000 & 0.702963 & -0.003031 & 0.180341 \\
\hline LIK & -0.104933 & 0.278978 & -0.730199 & 0.702963 & 1.000000 & -0.324449 & -0.098753 \\
\hline UP & -0.275804 & 0.294491 & 0.041861 & -0.003031 & -0.324449 & 1.000000 & -0.087104 \\
\hline $\mathrm{PL}$ & 0.083539 & -0.024136 & 0.057150 & 0.180341 & -0.098753 & -0.087104 & 1.000000 \\
\hline
\end{tabular}

Sumber: Hasil Olahan Eviews 10.0, 2020. 
Tabel 7. Uji Heteroskedastisitas

\begin{tabular}{|lccc|}
\hline \hline \multicolumn{1}{|c}{ Test } & Statistic & d.f. & Prob. \\
\hline \hline Breusch-Pagan LM & 68.61172 & 55 & 0.1027 \\
Pesaran scaled LM & 1.297827 & & 0.1943 \\
Pesaran CD & 0.612347 & & 0.5403 \\
\hline \hline
\end{tabular}

Sumber: Hasil Olahan Eviews 10.0, 2020.

Uji hipotesis memiliki tiga jenis pengujian yaitu sebagai berikut:

Tabel 8. Uji Kelayakan Model (F)

\begin{tabular}{|lr|}
\hline R-squared & 0.419552 \\
Adjusted R-squared & 0.325425 \\
S.E. of regression & 0.730771 \\
Sum squared resid & 19.75897 \\
Log likelihood & -44.82049 \\
\hline F-statistic & 4.457310 \\
Prob(F-statistic) & 0.001727 \\
\hline \hline
\end{tabular}

Sumber: Hasil Olahan Eviews 10.0, 2020.

Berdasarkan hasil tabel Fixed Effect Model yang ditampilkan pada tabel diatas menunjukkan bahwa nilai F-statistic sebesar 4.457310, sementara F-Tabel dengan tingkat $\alpha=5 \%$, df1 $(\mathrm{k}-1)=6$ dan df2 $(\mathrm{n}-\mathrm{k})=37$ didapat nilai $F$ Tabel sebesar 2.35. Dengan demikian F-statistic (4.457310) > F Tabel(2.36) dan nilai Prob(Fstatistic) $0.001727<0,05$ maka dapat disimpulkan bahwa $\mathrm{Ha}$ diterima, maka dengan demikian dapat disimpulkan bahwa penelitian ini layak untuk dilanjutkan karena variabel variabel independen dalam penelitian ini yang terdiri dari Investment Opportunity Set (IOS), Leverage, Profitabilitas, Likuiditas, Ukuran Perusahaan, dan Pertumbuhan Laba secara bersama-sama memiliki pengaruh terhadap variabel dependen Kualitas Laba.

Tabel 9. Uji Koefisien Determinasi

\begin{tabular}{|lr|}
\hline R-squared & 0.419552 \\
\hline Adjusted R-squared & 0.325425 \\
\hline S.E. of regression & 0.730771 \\
Sum squared resid & 19.75897 \\
Log likelihood & -44.82049 \\
F-statistic & 4.457310 \\
Prob(F-statistic) & 0.001727 \\
\hline \hline
\end{tabular}

Sumber Hasil Olahan Eviews 10.0, 2020.

Berdasarkan hasil tabel Common Effect Model yang ditampilkan pada tabel diatas menunjukkan Berdasarkan tabel di atas, menunjukkan bahwa nilai Adjusted R-squared sebesar 0.325425, artinya bahwa variasi perubahan naik turunnya Kualitas Laba dapat dijelaskan oleh Investment Opportunity Set (IOS), Leverage, Profitabilitas, Likuiditas, Ukuran Perusahaan, dan Pertumbuhan Laba sebesar 32.54 persen, sementara sisanya yaitu sebesar 67.46 persen dijelaskan olehvariabel - variabel lain yang tidak diteliti dalam penelitian ini. 
Tabel 10. Uji T Parsial

\begin{tabular}{|crrrr|}
\hline \hline Variable & Coefficient & Std. Error & \multicolumn{1}{c}{ t-Statistic } & \multicolumn{1}{c|}{ Prob. } \\
\hline \hline C & 3.602206 & 2.640556 & 1.364185 & 0.1808 \\
IOS & 0.106905 & 0.108326 & 0.986879 & 0.3301 \\
LEV & 0.028289 & 0.410984 & 0.068833 & 0.9455 \\
PROF & -15.88799 & 4.169144 & -3.810853 & 0.0005 \\
LIK & 0.256262 & 0.111013 & 2.308389 & 0.0267 \\
UP & -0.067155 & 0.083822 & -0.801160 & 0.4282 \\
PL & 0.916166 & 0.423574 & 2.162944 & 0.0371 \\
\hline \hline
\end{tabular}

Sumber: Hasil Olahan Eviews 10.0, 2020.

Hasil persamaan regresi yang diperoleh adalah:

$$
\begin{aligned}
& \mathrm{Y}=3.602206+0.106905 \mathrm{IOS}+0.028289 \mathrm{LEV}- \\
& 15.88799 \mathrm{PROF}+0.256262 \mathrm{LIK}-0.067155 \mathrm{UP} \\
& +0.916166 \mathrm{PL}+\varepsilon
\end{aligned}
$$

Gambar 2. Hasil Persamaan Regresi

Sumber: Data diolah penulis

\section{Pengaruh Investment Opportunity Set (IOS) terhadap Kualitas Laba}

Investment Opportunity Set (IOS) menunjukkan koefisien positif sebesar 0.106905 dengan tingkat signifikan $0.3301>\alpha=0,05$. Karena tingkat signifikan lebih besar dari $\alpha=0,05$ maka $\mathrm{H} 1$ ditolak sehingga kesimpulannya Investment Opportunity Set (IOS) adalah tidak berpengaruh terhadap Kualitas Laba.

Hasil Penelitian ini didukung dengan penelitian yang dilakukan oleh Helina dan Permanasari (2017), yang menyatakan bahwa Investment Opportunity Set (IOS) tidak berpengaruh terhadap pengungkapan Kualitas Laba. Namun penelitian ini tidak sejalan dengan penelitian yang dilakukan oleh Dewi (2018), yang menyatakan bahwa Investment Opportunity Set (IOS) berpengaruh negatif terhadap pengungkapan Kualitas Laba, serta hasil penelitian menurut Murniati, dkk (2018), yang menyatakan bahwa Investment Opportunity Set berpengaruh positif terhadap pengungkapan Kualitas Laba.

\section{Pengaruh Leverage terhadap Kualitas Laba}

Leverage menunjukkan koefisien positif sebesar 0.028289 dengan tingkat signifikan $0.9455>\alpha=0,05$. Karena tingkat signifikan lebih besar dari $\alpha=0,05$ maka $\mathrm{H} 2$ ditolak sehingga kesimpulannya Leverage adalah tidak berpengaruh terhadap Kualitas Laba.

Hasil Penelitian ini didukung dengan penelitian yang dilakukan Murniati, dkk (2018), yang menyatakan bahwa Leverage tidak berpengaruh terhadap pengungkapan Kualitas Laba. Namun penelitian ini tidak sejalan dengan penelitian yang dilakukan oleh Yasa, dkk. (2020), yang menyatakan bahwa Leverage berpengaruh negatif terhadap pengungkapan Kualitas Laba, serta hasil penelitian menurut Pitria (2017), 
yang menyatakan bahwa Leverage berpengaruh positif terhadap pengungkapan Kualitas Laba.

\section{Pengaruh Profitabilitas terhadap Kualitas Laba}

Profitabilitas menunjukkan koefisien negatif sebesar - 15.88799 dengan tingkat signifikan $0.0005<\alpha=0,05$. Karena tingkat signifikan lebih kecil dari $\alpha=0,05$ maka $\mathrm{H} 3$ diterima sehingga kesimpulannya adalah Profitabilitas berpengaruh terhadap Kualitas Laba dan memiliki arah yang negatif terhadap Kualitas Laba.

Hasil penelitian ini didukung dengan penelitian yang dilakukan oleh Laoli dan Herawaty (2019), yang menyatakan bahwa Profitabilitas memiliki pengaruh terhadap pengungkapan Kualitas Laba. Namun penelitian ini tidak sejalan dengan penelitian yang dilakukan oleh Ardianti (2018), yang menyatakan bahwa Profitabilitas berpengaruh positif terhadap pengungkapan Kualitas Laba, serta hasil penelitian menurut Ginting (2017), yang menyatakan bahwa Profitabilitas tidak memiliki pengaruh terhadap pengungkapan Kualitas Laba

\section{Pengaruh Likuiditas terhadap Kualitas Laba}

Likuiditas menunjukkan koefisien positif sebesar 0.256262 dengan tingkat signifikan $0.0267<\alpha=0,05$. Karena tingkat signifikan lebih kecil dari $\alpha=0,05$ maka $\mathrm{H} 4$ diterima sehingga kesimpulannya adalah Likuiditas berpengaruh terhadap Kualitas Laba dan memiliki arah yang positif terhadap Kualitas Laba.

Hasil penelitian ini didukung dengan penelitian yang dilakukan oleh (Ardianti, 2018), yang menyatakan bahwa Likuiditas memiliki pengaruh terhadap pengungkapan Kualitas Laba. Namun penelitian ini tidak sejalan dengan penelitian yang dilakukan oleh (Warianto dan Rusiti, 2014) yang menyatakan bahwa Likuiditas berpengaruh negatif terhadap pengungkapan Kualitas Laba, serta hasil penelitian menurut (Murniati, dkk., 2018), yang menyatakan bahwa Likuiditas tidak memiliki pengaruh terhadap pengungkapan Kualitas Laba.

\section{Pengaruh Ukuran Perusahaan terhadap Kualitas Laba}

Ukuran Perusahaan menunjukkan koefisien negatif sebesar 0.067155 dengan tingkat signifikan $0.4282>\alpha=0,05$. Karena tingkat signifikan lebih besar dari $\alpha=0,05$ maka $\mathrm{H} 5$ ditolak sehingga kesimpulannya adalah Ukuran Perusahaan tidak berpengaruh terhadap Kualitas Laba.

Hasil penelitian ini didukung dengan penelitian yang dilakukan oleh (Ginting, 2017) yang menyatakan bahwa Ukuran Perusahaan tidak memiliki pengaruh terhadap pengungkapan Kualitas Laba. Namun penelitian ini tidak sejalan dengan penelitian yang dilakukan oleh (Romasari, 2013) yang menyatakan bahwa Ukuran Perusahaan berpengaruh positif terhadap pengungkapan Kualitas Laba, serta hasil penelitian menurut (Warianto dan Rusiti, 2014), yang menyatakan bahwa 
Ukuran Perusahaan memiliki pengaruh negatif pengaruh terhadap pengungkapan Kualitas Laba.

\section{Pengaruh Pertumbuhan Laba terhadap Kualitas Laba}

Pertumbuhan Laba menunjukkan koefisien positif sebesar 0.916166 dengan tingkat signifikan $0.0371<\alpha=0,05$. Karena tingkat signifikan lebih kecil dari $\alpha=0,05$ maka $\mathrm{H} 6$ diterima sehingga kesimpulannya adalah Pertumbuhan Laba berpengaruh terhadap Kualitas Laba dan memiliki arah yang positif terhadap Kualitas Laba.

Hasil penelitian ini didukung dengan penelitian yang dilakukan oleh Yasa (2020) yang menyatakan bahwa Ukuran Perusahaan memiliki pengaruh positif terhadap pengungkapan Kualitas Laba. Namun penelitian ini tidak sejalan dengan penelitian yang dilakukan oleh Dewi (2018) yang menyatakan bahwa Ukuran Perusahaan berpengaruh negatif terhadap pengungkapan Kualitas Laba, serta hasil penelitian menurut Laoli dan Herawaty (2019), yang menyatakan bahwa Ukuran Perusahaan tidak memiliki pengaruh terhadap pengungkapan Kualitas Laba.

\section{KESIMPULAN}

Dilihat dari hasil penelitian yang telah dilakukan penulis, maka dapat disimpulkan:

1. Investment Opportunity Set (IOS) memiliki nilai t-statistic sebesar $(0.986879)$ < nilai t Tabel sebesar (2.02619) dan nilai Prob. 0.3301 > 0,05 maka dapat disimpulkan bahwa variabel Investment Opportunity Set (IOS) dalam penelitian ini tidak memiliki pengaruh terhadap kualitas laba karena semakin kecil tingkat Investment Opportunity Set (IOS) dengan demikian kualitas labanya semakin rendah.

2. Nilai t-statistic Leverage (LEV) sebesar $(0.068833)<$ nilai t Tabel (2.02619) dan nilai Prob. $0.9455>0,05$ maka dapat disimpulkan bahwa variabel Leverage (LEV) dalam penelitian ini tidak memiliki pengaruh terhadap kualitas laba namun leverage mempunyai arah positif terhadap kualitas laba dimana semakin kecil tingkat leverage dengan demikian kualitas laba suatu perusahaan akan semakin besar.

3. Nilai t-statistic Profitabilitas (PROF) sebesar $(-3.810853)>$ nilai t Tabel (2.02619) dan nilai Prob. $0.0005<0,05$ maka dapat disimpulkan bahwa variabel Profitabilitas (PROF) dalam penelitian ini memiliki pengaruh negatif dan signifikan terhadap kualitas laba dimana semakin kecil profitabilitas suatu perusahaan dengan demikian kualitas labanya akan semakin besar. Hal ini berbanding terbalik yang seharusnya jika semakin tingginya tingkat profitabilitas perusahaan maka kualitas labanya akan semakin besar.

4. Nilai t-statistic Likuiditas (LIK) sebesar (2.308389) > nilai t Tabel sebesar (2.02619) dan nilai Prob. $0.0267<0,05$ maka dapat disimpulkan bahwa variabel Likuiditas (LIK) dalam penelitian ini memiliki pengaruh terhadap kualitas laba dimana semakin kecilnya 
tingkat likuiditas dengan demikian kualitas laba suatu perusahaan akan semakin besar.

5. Nilai t-statistic Ukuran Perusahaan (UP) sebesar $(-0.801160)<$ nilai t Tabel (2.02619) dan nilai Prob. 0.4282 > 0,05 maka dapat disimpulkan bahwa variabel Ukuran Perusahaan (UP) dalam penelitian ini memiliki pengaruh negatif dan tidak signifikan terhadap kualitas laba dimana semakin kecil ukuran perusahaan maka kualitas labanya akan semakin tinggi.

6. Nilai t-statistic Pertumbuhan Laba (PL)sebesar (2.162944) > nilai t Tabel (2.02619) dan nilai Prob. $0.0371<0,05$ maka dapat disimpulkan bahwa variabel Pertumbuhan Laba(PL) dalam penelitian ini memiliki pengaruh positif terhadap kualitas laba, dimana semakin tinggi pertumbuhan laba suatu perusahaan dengan demikian kualitas labanya akan semakin tinggi pula.

Keterbatasan yang terdapat dalam penelitian ini yaitu :

1. Sampel penelitian ini hanya diambil pada satu sektor saja yaitu sektor Consumer goods industry yang terdaftar di BEI.

2. Penggunaan variabel yang digunakan dalam penelitian ini hanya berkaitan dengan rasio keuangan saja.

3. Penelitian ini hanya menggunakan periode penelitian yang singkat yaitu hanya 4 tahun periode saja,

Beberapa saran atau rekomendasi penulis untuk penelitian selanjutnya adalah sebagai berikut :

1. Untuk penelitian selanjutnya peneliti diharapkan dapat menambah jenis sektor perusahaan lainnya.

2. Untuk penelitian selanjutnya diharapkan dapat menggunakan variabel lain yang berpengaruh dan belum ada pada penelitian ini.

3. Diharapkan penelitian selanjutnya dapat menggunakan proksi lain dalam pengukuran masing-masing variabel.

4. Diharapkan penelitian selanjutnya dapat menambah jumlah tahun pengamatan agar hasil penelitian yang dilakukan lebih berkualitas.

\section{DAFTAR PUSTAKA}

Ardianti, R. (2018). Pengaruh Alokasi Pajak Antar Periode. Persistensi Laba, Profitabilitas dan Likuiditas Terhadap Kualitas Laba. Jurnal Akuntansi, 6(1), 88-105.

Dewi, C. (2018). Pengaruh Ukuran Perusahaan, Struktur Modal, Likuiditas, Investmen Opportunity Set dan Pertumbuhan Laba Terhadap Kualitas Laba Perusahaan (Studi pada Perusahaan Manufaktur yang terdaftar di Bursa Efek Indonesia periode 2014-2016). 1, 1-93. https://doi.org/ISSN 2252-6765.

Eksandy, Arry. 2018. Metode Penelitian Akuntansi dan Manajemen. Tangerang: FEB UMT. 
Ginting, S. (2017). Pengaruh Profitabilitas, Likuiditas Dan Ukuran Perusahaan Terhadap Kualitas Laba Pada Perusahaan Manufaktur Yang Terdaftar Di Bursa Efek Indonesia. Jurnal Wira Ekonomi Mikroskil, 7(2), 227-236.

Hakim, M. Z., \& Abass, DS. (2019, Agustus). Pengaruh Ukuran Perusahaan, Struktur Modal, Likuiditas, Investment Opportunity Set (IOS), dan Profitabilitas Terhadap Kualitas Laba pada Perusahaan Makanan dan Minuman yang Terdaftar di Bursa Efek Indonesia Tahun 2013-2017. Competitive, 3(2), 26-51.

Helina, \& Permanasari, M. (2018). Faktor-faktor yang mempengaruhi kualitas laba pada perusahaan manufaktur. Jurnal Bisnis Dan Akuntansi, 19(1), 47-55. https://doi.org/10.34208/jba.v19i1.64

Laoli, A. N., \& Herawaty, V. (2019). Pengaruh Profitabilitas, Growth, Leverage, Operating Cycle Dan Prudence Terhadap Kualitas Laba Dengan Firm Size Sebagai Variabel Moderasi. Prosiding Seminar Nasional Cendekiawan, 2000, 2.39.1-2.39.7. https://doi.org/10.25105/semnas.v0i0.5828

Murniati, T., Sastri, I. I. D. A. M. M. S., \& I Wayan Rupa. (2018). Faktor Faktor Yang Mempengaruhi Kualitas Laba Pada Perusahaan Manufaktur Yang Terdaftar Di Bei Tahun 2012 - 2016. Kumpulan Riset Akuntansi, 10(1), 89-101. https://ejournal.warmadewa.ac.id/index.php/krisna

Novianti, R. (2012). Kajian Kualitas Laba Pada Perusahaan Manufaktur Yang Terdaftar Di Bei. Accounting Analysis Journal, 1(2), 1-6. https://doi.org/10.15294/aaj.v1i2.656

Setiawan, B. R. (2017). Pengaruh Ukuran Perusahaan,Profitabilitas, Likuiditas dan Leverage terhadap Kualitas Laba. MENARA IImu, XI(77), 36-46.

Warianto, P., \& Rusiti, C. (2014). Pengaruh Ukuran Perusahaan, Struktur Modal, Likuiditas Dan Investment Opportunity Set (los) Terhadap Kualitas Laba Pada Perusahaan Manufaktur Yang Terdaftar Di Bei. Modus, 26(1), 19-32. https://doi.org/10.24002/modus.v26i1.575

Wulansari, Y. (2013). Pengaruh Investment Opportunity Set, Likuiditas dan Leverage Terhadap Kualitas Laba Pada Perusahaan Manufaktur Yang Terdaftar di BEI. 1-31.

https://www.idnfinancials.com. (28 Maret 2018 15:21). Citing Internet sources URL https://www.idnfinancials.com/archive/id/news/15424/Akasha-Wiraprofit-drops-316-yoy

https://www.idx.co.id/ 